\title{
Influence of gametogenesis pattern and sex on paralytic shellfish toxin levels in triploid Pacific oyster Crassostrea gigas exposed to a natural bloom of Alexandrium minutum
}

\author{
Hermabessiere Ludovic ${ }^{1}$, Fabioux C. ${ }^{1}$, Lassudrie M. ${ }^{1}$, Boullot F. ${ }^{1}$, Long M. ${ }^{1}$, Lambert C. ${ }^{1}$, \\ Le Goïc N. ${ }^{1}$, Gouriou Jeremie ${ }^{2}$, Le Gac Mickael ${ }^{3}$, Chapelle Annie ${ }^{3}$, Soudant P. ${ }^{1}$, Hégaret Helene ${ }^{1,{ }^{*}}$
}

${ }^{1}$ Laboratoire des Sciences de I'Environnement Marin LEMAR-UMR6539, Institut Universitaire Européen de la Mer, Université de Bretagne Occidentale, Place Copernic, Technopôle Brest-Iroise, 29280

Plouzané, France

${ }^{2}$ Ifremer, Station de Biologie Marine, Place de la Croix, 29185 Concarneau, France

${ }^{3}$ Ifremer, Dyneco/Pelagos, ZI de la Pointe du Diable, CS10070, 29280 Plouzané, France

* Corresponding author : Helene Hégaret, email address : helene.hegaret@univ.brest.fr

\begin{abstract}
:
This study investigated the effect of gametogenesis pattern and sex on levels of paralytic shellfish toxins (PST) accumulated by triploid oysters Crassostrea gigas exposed to a natural bloom of the toxic dinoflagellate Alexandrium minutum in the Bay of Brest (Western Brittany, France), over the summer 2014. Toxin accumulation in oysters was proposed to be influenced by the proportion of energy allocated to reproduction versus other metabolisms, as proposed by Haberkorn et al. (2010). Thus, we hypothesized that triploid oysters with different gametogenesis patterns ( $\alpha$ or $\beta$, producing respectively numerous gametes or rare gametes) could result in differences in toxin accumulation. Toxin level could also be different according to the gender of the oysters. To test these hypotheses, PST levels were measured in the digestive gland of oysters using an ELISA method. Sex, gametogenesis stage and pattern $(\alpha$ or $\beta$ ) of the triploid oysters were determined by histology. Males $(24 \%)$, females $(38 \%)$ and hermaphrodites (38\%), including synchronous or successive hermaphrodites were represented among the sampled oysters. All of them were at mature stage (III) of gametogenesis. Both $\alpha(46 \%)$ and $\beta(54 \%)$ patterns were represented in the sample set. In these oysters, PST levels appeared independent from sex and gametogenesis pattern. These results suggest that, in triploid oysters, PST accumulation is not influenced by energy allocated to reproduction.
\end{abstract}

Statement of relevance

This study appears to be the first to investigate toxin levels depending on gametogenesis pattern in triploid oysters.

This study highlighted that triploid oysters were divided into two classes, $\alpha$ (triploid oysters that maturate with unlocked germ cells and have a consequent number of gametes) and $\beta$ (triploid oysters that display strongly reduced number of gametes and locked gonial mitosis), with the latter class subdivided into two categories: $\beta 1$, which presents no germinal cell lineage, and $\beta 2$, which presents germinal cell lineage. 
This study showed that toxin levels in the digestive glands of triploids were not significantly different, neither between gametogenesis patterns nor between sexes. Additionally, despite the different patterns of gametogenesis in the triploid oysters of the present study, no difference in toxin levels accumulated in the digestive glands was detected between $\alpha$ and $\beta$ oysters, suggesting that reproductive investment in triploid oysters does not influence toxin accumulation.

\section{Highlights}

- Triploid Crassostrea gigas were exposed to a natural bloom of Alexandrium minutum. does not seem to influence paralytic shellfish toxin levels in triploid oysters. Gametogenesis pattern does not seem to influence paralytic shellfish toxin levels in triploid oysters. Fifty percent of sampled triploid oysters showed a pattern, producing numerous mature gametes.

Keywords : Crassostrea gigas, Alexandrium minutum, Harmful algal bloom (HAB), Paralytic shellfish toxin (PST), Gametogenesis pattern, Triploid 


\section{Introduction}

Production of the Pacific oyster Crassostrea gigas reached 4.8 millions of tons worldwide in 2013 (FAO, 2015), mostly produced by aquaculture. Triploid Pacific oysters are nowadays commonly used in aquaculture (Nell, 2002) as they exhibit numerous advantages compared to diploid oysters: a faster growth (Allen and Downing, 1986; Normand et al., 2009) and a reduced gonadic development (Allen and Downing, 1990; Nell, 2002; Normand et al., 2008) that facilitates commercialization over the summer. However gametogenesis is not totally absent in triploid oysters (Allen and Downing, 1990; Jouaux et al., 2010; Normand et al., 2008). A recent study (Jouaux et al., 2010) divided triploid oysters into two main classes according to their gametogenesis pattern: the $\alpha$ and the $\beta$ triploids. Alpha-pattern triploid oysters produced numerous mature gametes (unlocked gametogenesis), reaching almost 50\% of the reproductive investment of the diploid oysters, while $\beta$-pattern triploid oysters displayed only few mature gametes corresponding to locked gametogenesis (Jouaux et al., 2010). Moreover, $\beta$ triploids could be separated into two categories: $\beta 1$ triploids, which present no germinal cell lineage, and $\beta 2$ triploids, which present germinal cell lineage (Jouaux et al., 2010). Such differences in gametogenesis status among triploid oysters make them an interesting model to study individuals with different reproductive investment but similar ploidy.

Harmful algal blooms (HAB) occur worldwide (Van Dolah, 2000) and appear to be increasing in duration and extent in many locations (Anderson et al., 2002). Several toxic microalgal species can be responsible for HABs, such as species of the genus Alexandrium. These microalgal species are known to produce paralytic shellfish toxins (PST) and are responsible for paralytic shellfish poisoning (PSP) syndrome in human, caused by the consumption of contaminated shellfish that feed on these algae and accumulate toxins. Consequently, these blooms can have economic impacts on the aquaculture industry by leading to closures of 
shellfish harvest (Bricelj and Shumway, 1998). In France, recurrent shellfish sale closures occur due to blooms of Alexandrium sp., particularly Alexandrium minutum Halim in Brittany (Chapelle et al., 2008, 2015; Lassus et al., 1994, 2004) and Alexandrium catenella Balech (Whedon \& Kofoid) in Thau Lagoon. These blooms particularly impact the industry of $C$. gigas, since France is the first European producer (79 000 tons in 2013; FAO, 2015).

Identifying the factors that influence toxin accumulation in oysters appears thus to be an important challenge for the shellfish industry. Recent in lab exposure experiments suggested that PST accumulation in C. gigas was dependent on the gametogenesis status (Guéguen et al., 2012). In fact, after exposure to the same concentration of cultured A. minutum, triploid oysters accumulated about twice as much toxins as diploid oysters during the sexual maturation period only, whereas no difference was detected during the sexual resting period (Guéguen et al., 2012; Haberkorn et al., 2010). Filtration and clearance rates were similar between diploids and triploids, and thus could not explain these differences in accumulation (Guéguen et al., 2012; Haberkorn et al., 2010). Haberkorn et al. (2010) hypothesized that the toxin load differences between diploid and triploid oysters could be due to difference in metabolic and/or feeding related activities. Triploid oysters, supposedly involving less energy in reproduction, would have more energy to assimilate, grow and thus accumulate more toxins rather than diploid oysters. Therefore, triploid oysters with different gametogenesis pattern ( $\alpha$ versus $\beta$ ) could have different toxin load. Moreover, no information is available regarding the influence of sex on reproductive investment in triploid $C$. gigas, which could also influence toxin levels. To test these hypotheses, the present study compared PST accumulation in triploid oysters with different reproductive investment (according to gametogenesis pattern and/or sex), exposed to a natural bloom of A. minutum. PST accumulation in triploids $C$. gigas were measured by ELISA method, with regards to their maturation stages, sex and $\alpha$ versus $\beta$ ( $\beta 1$ and $\beta 2$ ) gametogenesis status using histological analyses. 


\section{Material and methods}

\subsection{Study site}

The study site was located in the bay of Daoulas in the bay of Brest (Western Brittany, France) (Figure 1), where the highest concentrations of important blooms of A. minutum have been occurring since 2012 (Chapelle et al., 2015).

\subsection{Experimental oysters and sampling}

Forty nine triploid Crassostrea gigas oysters grown in the Bay of Paimpol (Northern Brittany, France), where no Alexandrium sp. bloom occurs, were obtained from an oyster farmer on June $18^{\text {th }} 2014$. Ten of these oysters were immediately sampled to measure shell length, shell weight and wet flesh weight, to be used as reference $T_{0}$ point to assess growth during the exposure.

Thirty nine oysters were put on the study site on June $18^{\text {th }}$, the same day they were received, when A. minutum concentrations reached 403000 cells $\mathrm{L}^{-1}$. Oysters were left on site, thus exposed to the natural A. minutum bloom, before being removed from the study site, 38 days later, on July $25^{\text {th }}$.

For each of the 39 oysters, shell length, shell weight and wet flesh weight were measured prior to dissections. The digestive gland was dissected, weighed and stored at $-80{ }^{\circ} \mathrm{C}$ until further analysis. A piece of $1 \mathrm{~mm}^{2}$ of gill tissue was sampled and placed in an Eppendorf tube at $-80{ }^{\circ} \mathrm{C}$ for ploidy analysis. Additionally, a $5 \mathrm{~mm}$ cross section of the visceral mass including gills, mantle, gonad and digestive gland was sampled and fixed in Davidson for 48 h at $4{ }^{\circ} \mathrm{C}$ before being transferred to $70 \%$ ethanol and stored at $4{ }^{\circ} \mathrm{C}$ for histology analyses. 


\subsection{Condition index}

Condition index (CI) was calculated for oysters sampled before and after exposure according to Lucas and Beninger, (1985):

$$
C I=\frac{\text { wet flesh weight }}{\text { total wet weight }}
$$

\subsection{Ploidy measurement}

Ploidy was tested individually for all triploid oysters using flow cytometry and propidium iodide (PI) DNA staining (Normand et al, pers. com.). Briefly, $1 \mathrm{~mm}^{2}$ of gill tissue was suspended in $1 \mathrm{~mL}$ of the following mixture: for $10 \mathrm{~mL}: 9.525 \mathrm{~mL}$ of extraction buffer $\left(\mathrm{MgCl}_{2}-6 \mathrm{H}_{2} \mathrm{O}, 0.0107 \mathrm{~g}\right.$; $\mathrm{NaCl} 0.05 \mathrm{~g}$; Trizmabase $0.1211 \mathrm{~g}$, Triton X100 $10 \mu \mathrm{L}$, QS $\mathrm{H}_{2} \mathrm{O}$, $\mathrm{Ph} 7), 250 \mu \mathrm{L}$ of PI solution (1 $\mathrm{mg} \mathrm{mL}^{-1}$ in distilled water, Sigma), $25 \mu \mathrm{L}$ of RNAse A solution (10 $\mathrm{mg} \mathrm{mL}^{-1}$ in distilled water, Sigma R4875) and $4 \mu \mathrm{L}$ of yellow-green fluorescent 1 $\mu \mathrm{m}$ bead solution (2\% in sterile filtered seawater, Fluoresbrite ${ }^{\circledR}$ YG Microspheres $1.00 \mu \mathrm{m}$, Polyscience). After gentle pipetting and vortexing, the total volume was transferred into a 5 $\mathrm{mL}$ flow cytometer tube by filtering through an $80 \mu \mathrm{m}$ mesh sieve in order to eliminate debris or aggregates able to clog the flow cytometer. Samples were then incubated at $18{ }^{\circ} \mathrm{C}$ during $30 \mathrm{~min}$ in the dark.

Extraction buffer allowed the extraction of the nucleus from gill cells. PI ( $\lambda$ ex $=536 \mathrm{~nm}, \lambda \mathrm{em}$ $=617 \mathrm{~nm}$ ) was used to assess DNA content. Indeed PI binds to DNA and its fluorescence intensity is proportional to the DNA cell content. Since PI can also bind to double-stranded RNA, RNase was added to eliminate the RNA chains for optimal DNA resolution. Beads were added as an internal standard for flow-cytometer fluorescence level control.

Samples were then analyzed for $60 \mathrm{sec}$ at low flow rate $\left(\sim 15 \mu \mathrm{L} \mathrm{min}^{-1}\right)$ on a FacsCalibur flow cytometer (Becton Dickinson) equipped with an air-cooled laser (15 mW, $488 \mathrm{~nm})$, as described by da Silva et al. (2005). Triploid oysters could be distinguished according to the 
level of PI fluorescence (orange detector, FL2, of the flow-cytometer: 585/42 nm, BP) of single nucleus (Figure 2).

\subsection{Toxin detection}

Paralytic shellfish toxin (PST) levels were measured using the saxitoxin (PSP) ELISA kit (Abraxis) as described by Lassudrie et al. (2015a; 2015b). Oyster digestive glands were ground in $\mathrm{HCl} 0.1 \mathrm{M}(1: 1 \mathrm{w:v})$ and boiled for $5 \mathrm{~min}$ at $100{ }^{\circ} \mathrm{C}$, following the manufacturer instructions. This step led to acid hydrolysis that induces chemical conversion of some PST analogues to STX. Debris were then eliminated by centrifugation at $3500 \mathrm{~g}$ during $10 \mathrm{~min}$ and the supernatant was recovered for ELISA. As the ELISA recognizes mostly STX, results were

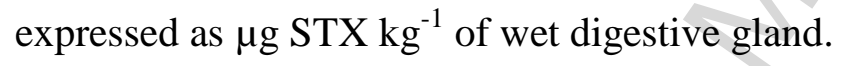

\subsection{Histology: gametogenesis pattern and sex identification}

The cross sections previously fixed in Davidson solution were dehydrated in ascending solutions of ethanol, cleared using Claral solutions and fixed in paraffin wax. Five $\mu \mathrm{m}$ sections were cut and mounted on glass slides. For each sample, one slide was stained using Harris' hematoxylin-eosin (Steele and Mulcahy, 1999). Slides were observed under a light microscope (Leica DMIRB) equipped with a digital camera (Imaging RETIGA 2000R) allowing sex, gametogenesis stage and pattern identification.

Gametogenesis stages were identified as described by Jouaux et al. (2010) and Franco et al., (2008). Briefly, stage 0 corresponded to sexual resting stage, stage I to gonial mitosis, stage II to the development of germinal lineage and stage III to sexual maturation. Gametogenesis patterns of triploid oysters were identified according to Jouaux et al. (2010): individuals presenting unlocked cellular division at stage I and II or numerous gametes at stage III were classified as $\alpha$, whereas individuals presenting locked cellular division and very few gametes 
at stage III were classified as $\beta$. $\beta$ triploid oysters were also classified into two categories depending on the absence $(\beta 1)$ or the presence $(\beta 2)$ of a continuum in germ cell lineage at maturity (Jouaux et al., 2010). Finally, sex identification was also performed, assessing male, female and hermaphrodite individuals, including both synchronous and asynchronous hermaphrodites (Jouaux et al., 2010).

\subsection{Statistical analyses}

Two-way ANOVA was used to test the effects of both sex and gametogenesis pattern ( $\alpha$ and $\beta$ ) on toxin levels in triploid oysters, after normality and homoscedasticity assumptions were verified.

Student t-test was used to analyze differences in toxin levels between triploid $\beta 1$ and $\beta 2$ and to test differences in biometric measurements between oysters sampled at $\mathrm{T}_{0}$ (before exposure) and after over a month of exposure in the field, between triploid oysters $\alpha$ and $\beta$ and between triploid oysters $\beta 1$ and $\beta 2$. Normality and homoscedasticity assumptions were tested prior to t-tests. When homoscedasticity was not respected, t-tests were performed using the Welch correction.

Fisher exact test was used to test differences of distribution between $\alpha$ and $\beta$ triploid oyster and sex.

Differences were considered significant when $p$-value $<0.05$. Statistics were performed using $\mathrm{R}$ version 3.2.0 (R Core Team, 2015). All results are expressed as mean \pm standard error. 


\section{Results}

\subsection{Ploidy measurement}

Analyses using flow cytometry confirmed that all oysters were triploid.

\subsection{Sex and gametogenesis pattern}

All 39 exposed triploid oysters reached stage III of gametogenesis, corresponding to ripeness. Histological identification of gametogenesis pattern showed that $46 \%$ of oysters were $\alpha$ triploids and 54\% were $\beta$ triploids (Table 1 - Figure 3 A-F). For $\beta$ triploids, $7 \beta 1$ and $14 \beta 2$ oysters were identified using histological slides. Moreover, 2 males, 2 females and 3 hermaphrodites were $\beta 1$ and 4 males, 2 females and 8 hermaphrodites were $\beta 2$ (Figure 3 G-J). A significant difference in the distribution of $\alpha$ and $\beta$ triploids was observed depending on sex (Fisher test; p-value <0.05). Indeed, males and hermaphrodites appeared mostly $\beta$, whereas most of the females were $\alpha$ (Table 1 ).

\subsection{Biometric measurements}

Before exposure, oysters measured $54.6 \pm 2.6 \mathrm{~mm}$ mean height had a total mean wet weight of $12.6 \pm 1.1 \mathrm{~g}$ and had a mean condition index $(\mathrm{CI})$ of $0.19 \pm 0.01(\mathrm{n}=10)$.

After 38 days of exposure in the field during the natural bloom of Alexandrium minutum, significant increases (t-tests; $\mathrm{p}<0.05)$ in mean length $(64.3 \pm 1.8 \mathrm{~mm})$, mean total wet weight $(21.8 \pm 3.4 \mathrm{~g})$ and CI $(0.25 \pm 0.01)$ were measured $(\mathrm{n}=39)$. No significant differences (t-test; $\mathrm{p}>0.05)$ were found between triploids $\alpha$ and $\beta$ for length $(62.3 \pm 2.8 \mathrm{~mm}$ and $65.9 \pm 2.2 \mathrm{~mm}$, respectively), total wet weight $(21.1 \pm 1.6 \mathrm{~g}$ and $22.4 \pm 1.4 \mathrm{~g}$, respectively) and CI $(0.24 \pm$ 0.01 and $0.25 \pm 0.005$, respectively). Moreover, no difference (t-tests; $p>0.05$ ) was found between triploids $\beta 1$ and $\beta 2$ for length $(64.8 \pm 4.2 \mathrm{~mm}$ and $66.5 \pm 2.7 \mathrm{~mm}$, respectively), total 
wet weight $(24.4 \pm 2.9 \mathrm{~g}$ and $22.9 \pm 1.5 \mathrm{~g}$, respectively) and CI $(0.25 \pm 0.01$ and $0.25 \pm 1.50$, respectively).

\subsection{Toxin levels}

Paralytic shellfish toxin (PST) levels, measured in the digestive gland by ELISA, did not differ significantly between triploid oysters depending on sex or gametogenesis pattern ( $\alpha$ or ß) (two-way ANOVA, Figure 4).

No significant differences ( $\mathrm{t}$-tests; $\mathrm{p}>0.05$ ) were observed in PST levels between the two $\beta$ status ( $\beta 1$ and $\beta 2$ ) and the $\alpha$ status in triploids, regardless of the sex (Figure 5).

\section{Discussion}

The aim of this study was to test the hypotheses that sex, maturation stage and gametogenesis pattern would influence toxin levels in the digestive gland of triploid oysters Crassostrea gigas exposed to a natural bloom of Alexandrium minutum. This work focused on triploid oysters since they are commonly used by oyster farmers (Nell, 2002), due to their fast growth and reduced ripeness during summer, that is more appreciated by consumers. Additionally, unlike diploid oysters, they present different gametogenesis patterns, allowing comparison of oysters with different reproductive investment. This study appears to be the first to investigate toxin levels depending on gametogenesis pattern in triploid oysters. Despite the relatively low number of triploid oysters exposed to the natural bloom of A. minutum (39 oysters), all categories for sex and gametogenesis patterns were represented in this sample allowing statistical analyses.

As described by Jouaux et al. (2010), triploids were divided into two classes, $\alpha$ and $\beta$. Alphaclass corresponds to triploid oysters that maturate with unlocked germ cells and have a 
consequent number of gametes. Beta-class displays strongly reduced number of gametes and locked gonial mitosis. This latter class is subdivided into two categories: $\beta 1$, which presents no germinal cell lineage, and $\beta 2$, which presents germinal cell lineage (Jouaux et al., 2010). In this study, $46 \%$ of the exposed oysters were $\alpha$, which is more than described elsewhere (Jouaux et al., 2010, 2013). Jouaux et al. (2013) observed a higher percentage of $\alpha$-class when triploids were fed with a nutritional conditioning diet (27\%) compared to unfed triploids (16\%). Thus, the higher proportion of $\alpha$ triploids observed in our study compared to other studies may reflect a better nutritional quality of the diet during the field exposure than the cultured-algal diets provided in Jouaux et al. $(2010,2013)$. In fact, field diets are known to present a better nutritional quality for bivalves than artificial conditioning diets (Soudant $e t$ al., 1999, Dudognon et al., 2015)

Accordingly, during the exposure to the A. minutum bloom, the oyster diet in the field enabled growth, as assessed by the higher shell height, total weight and CI in oysters after 38 days of exposure, compared to oysters sampled before exposure. No significant difference in these biometric measurements was detected between triploid $\alpha$ and $\beta$, and between $\beta 1$ and $\beta 2$. Oysters kept growing despite the presence of the toxic dinoflagellates, and appeared to keep filtering and feeding, as assessed by the accumulation of PST in their digestive glands.

Toxin levels in the digestive glands of triploids were not significantly different, neither between gametogenesis patterns nor between sexes. These toxin levels are in accordance with two other in vivo studies (Guéguen et al., 2012 ; Haberkorn et al., 2010), which exposed oysters to an important concentration of $A$. minutum during a short period.

Despite the different patterns of gametogenesis in the triploid oysters of the present study, no difference in toxin levels accumulated in the digestive glands was detected between $\alpha$ and $\beta$ oysters, suggesting that reproductive investment in triploid oysters does not influence toxin accumulation. Considering that all triploid oysters in the present study reached stage III, and 
that gonadal occupation in $\alpha$ triploids was reported by Jouaux et al., (2010) to be important, reaching about $50 \%$ to $75 \%$ of what was found in diploids, it is very likely that $\alpha$ triploids invest an important amount of energy in reproductive effort compare to $\beta$ triploids.

Moreover, different energy allocation strategies between $\alpha$ and $\beta$ triploids were highlighted by Jouaux et al., (2013) : whereas unfed $\beta$ triploids always presented residual reserves associated to low gonial proliferation, $\alpha$ triploid oysters did not present any residual reserves, similarly to diploid oysters.

Previous studies suggested that differences in reproductive investment between diploid and triploid Pacific oysters impacted PST accumulation (Guéguen et al., 2012 ; Haberkorn et al., 2010). However, in the present study, the hypothesis that triploid oysters with different reproductive investments would lead to differential toxin accumulation was not supported when oysters were exposed to a natural bloom. One could argue that PST could have been accumulated in other organs than the digestive glands, particularly in the gonads, which were not assessed in this study. However, such a bias is unlikely, considering that a preliminary study (data not shown) indicated that the digestive glands of triploid oysters concentrated over $70 \%$ of the PST content of the whole body, in agreement with other studies (Bricelj and Shumway, 1998). Aditionally, in a parallel study, oocytes of mature diploid C. gigas exposed to A. minutum contained about 200-fold less PST than in the digestive glands (N. Le Goïc, pers. comm.).

Therefore, results of the present study suggest that another mechanism, not directly associated with reproductive investment, would drive toxin accumulation kinetics. A hypothesis is that different assimilation rates between mature diploid and triploid oysters, due to different metabolic activities, would explain toxin accumulation differences observed by Guéguen et al. (2012) and Haberkorn et al. (2010). Further studies assessing ecophysiological variables such as respiration, filtration, absorption, assimilation and digestion rates would help to 
understand mechanisms involved in differential toxin accumulation between individual oysters.

Other factors also may influence toxin accumulation in oysters. In fact, unlike Guéguen et al. (2012) and Haberkorn et al. (2010) studies, the present study was performed with a natural $A$. minutum exposure, possibly including some unknown, environmental factors that may have confounding effects on toxin accumulation, but also being more realistic. Finally, further studies using diploid and triploid oysters with the same genetic origins (same parents), at different times of the year, including spawning season, are needed to further investigate the involvement of reproduction, gametogenesis and energy status in oyster toxin accumulation.

\section{Acknowledgements}

This project was supported by the Region Bretagne, which supported the Daoulex project, by the Fondation de France, with the PHENOMER project and the ANR CESA, which supported the ACCUTOX project. The authors gratefully acknowledge the in situ REPHY and VELYGER networks. The authors are also grateful to Julien Coïc for providing oysters and for his help during this field sampling and to Yoann Thomas for his help on improving the discussion. 


\section{References}

Allen, S.K., Downing, S.L., 1986. Performance of triploid Pacific oysters, Crassostrea gigas (Thunberg). I. Survival, growth, glycogen content and sexual maturation in yearlings. Journal of Experimental Marine Biology and Ecology 102, 197-208.

Allen, S.K., Downing, S.L., 1990. Performance of triploid Pacific Oysters, Crassostrea gigas : Gametogenesis. Canadian Journal of Fisheries and Aquatic Sciences 47, 1213-1222.

Anderson, D.M., Glibert, P.M., Burkholder, J.M., 2002. Harmful algal blooms and eutrophication: Nutrient sources, composition, and consequences. Estuaries 25, 704726.

Bricelj, V.M., Shumway, S.E., 1998. Paralytic Shellfish Toxins in Bivalve Molluscs: Occurrence, Transfer Kinetics, and Biotransformation. Reviews in Fisheries Science 6, $315-383$.

Chapelle A., Andrieux-Loyer F., Fauchot, J., Guillaud, J.F., Labry, C., Sourisseau, M., Verney, R., 2008. Understanding, predicting and tackling algal blooms. "What is the current situation concerning Alexandrium minutum in the Penzé estuary?". Ifremer report. $23 \mathrm{p}$.

Chapelle A., Le Gac M., Labry C., Siano R., Quere J., Caradec F., Le Bec C., Nezan E., Doner A., Gouriou J., 2015. The Bay of Brest (France), a new risky site for toxic Alexandrium minutum bloom and PSP shellfish contamination. Harmful Algae News $51,4-5$.

da Silva, P.M., Soudant, P., Carballal, M.J., Lambert, C., Villalba, A., 2005. Flow cytometric DNA content analysis of neoplastic cells in haemolymph of the cockle Cerastoderma edule. Diseases of Aquatic Organisms 67, 133-139. 
Dudognon, T., Guderley, H., Quéré, C., Soudant, P., Racotta, I. S., \& Kraffe, E., 2015. Laboratory conditioning modifies properties of gills mitochondria from the Pacific oyster Crassostrea gigas. Marine Biology, 162, 1033-1045.

FAO, 2015. Fisheries and Aquaculture Information and Statistics Service, Global Production $\begin{array}{llll}\text { Statistics } & \text { [WWO-2013 Document]. URL }\end{array}$ <http://www.fao.org/fishery/statistics/global-production/query/fr> $>$ (accessed 15.07.2015).

Franco, A., Berthelin, C.H., Goux, D., Sourdaine, P., Mathieu, M., 2008. Fine structure of the early stages of spermatogenesis in the Pacific oyster, Crassostrea gigas (Mollusca, Bivalvia). Tissue \& Cell 40 (4), 251-260.

Guéguen, M., Baron, R., Bardouil, M., Haberkorn, H., Soudant, P., Truquet, P., Lassus, P., 2012. Influence of Crassostrea gigas (Thunberg) sexual maturation stage and ploidy on uptake of paralytic phycotoxins. Toxicon 60, 40-43.

Haberkorn, H., Lambert, C., Le Goïc, N., Guéguen, M., Moal, J., Palacios, E., Lassus, P., Soudant, P., 2010. Effects of Alexandrium minutum exposure upon physiological and hematological variables of diploid and triploid oysters, Crassostrea gigas. Aquatic Toxicology 97, 96-108.

Jouaux, A., Blin, J.L., Adeline, B., Heude-Berthelin, C., Sourdaine, P., Mathieu, M., Kellner, K., 2013. Impact of energy storage strategies on gametogenesis and reproductive effort in diploid and triploid Pacific oysters Crassostrea gigas - Involvement of insulin signaling. Aquaculture 388, 173-181.

Jouaux, A., Heude-Berthelin, C., Sourdaine, P., Mathieu, M., Kellner, K., 2010. Gametogenic stages in triploid oysters Crassostrea gigas: Irregular locking of gonial proliferation and subsequent reproductive effort. Journal of Experimental Marine Biology and Ecology 395, 162-170. 
Lassudrie, M., Soudant, P., Nicolas, J.-L., Fabioux, C., Lambert, C., Miner, P., Le Grand, J., Petton, B., Hégaret, H., 2015a. Interaction between toxic dinoflagellate Alexandrium catenella exposure and disease associated with herpesvirus OsHV-1 $\mu$ Var in Pacific oyster spat Crassostrea gigas. Harmful Algae 45, 53-61.

Lassudrie, M., Wikfors, G.H., Sunila, I., Alix, J.H., Dixon, M.S., Combot, D., Soudant, P., Fabioux, C., Hégaret, H., 2015b. Physiological and pathological changes in the eastern oyster Crassostrea virginica infested with the trematode Bucephalus $s p$ and exposed to the toxic dinoflagellate Alexandrium fundyense. Journal of Invertebrate Pathology $126,51-63$.

Lassus, P., Baron, R., Garen, P., Truquet, P., Masselin, P., Bardouil, M., Leguay, D., Amzil, Z., 2004. Paralytic shellfish poison outbreaks in the Penzé estuary: Environmental factors affecting toxin uptake in the oyster, Crassostrea gigas. Aquatic Living Resources 17, 207-214.

Lassus, P., Ledoux, M., Bardouil, M., Bohec, M., Erard, E., 1994. Kinetics of Alexandrium minutum Halim toxin accumulation in mussels and clams. Natural Toxins 2, 329-333.

Lucas, A., Beninger, P.G., 1985. The use of physiological condition indices in marine bivalve aquaculture. Aquaculture 44, 187-200.

Nell, J.A., 2002. Farming triploid oysters. Aquaculture 210 (1-4), 69-88.

Normand, J., Ernande, B., Haure, J., McCombie, H., Boudry, P., 2009. Reproductive effort and growth in Crassostrea gigas: comparison of young diploid and triploid oysters issued from natural crosses or chemical induction. Aquatic Biology 7, 229-241.

Normand, J., Le Pennec, M., Boudry, P., 2008. Comparative histological study of gametogenesis in diploid and triploid Pacific oysters (Crassostrea gigas) reared in an estuarine farming site in France during the 2003 heatwave. Aquaculture 282, 124-129. 
Soudant, P., Van Ryckeghem, K., Marty, Y., Moal, J., Samain, J.F., Sorgeloos, P., 1999. Comparison of the lipid class and fatty acid composition between a reproductive cycle in nature and a standard hatchery conditioning of the Pacific Oyster Crassostrea gigas. Comparative Biochemistry and Physiology B-Biochemistry \& Molecular Biology 123, 209-222.

Steele, S., Mulcahy, M.F., 1999. Gametogenesis of the oyster Crassostrea gigas in southern Ireland. Journal of the Marine Biological Association of the United Kingdom 79, 673686.

Van Dolah, F.M., 2000. Marine algal toxins: Origins, health effects, and their increased occurrence. Environmental Health Perspectives 108, 133-141. 


\section{Figure legends}

Figure 1: Study site (bay of Daoulas) located in the bay of Brest (Western Brittany, France)

Figure 2: Typical cytograms and histograms (software, FacsSuite, Becton Dickinson) obtained for ploidy analysis on nucleus isolated from oyster gills (Crassostrea gigas) stained with Propidium Iodide (PI); A and C: cytograms FL2 area = f (FL2 Width) allowing elimination of doublets, FL2 = fluorescence detector $n^{\circ} 2(485 / 42 \mathrm{~nm})$ corresponding to the fluorescence level of PI, ie the DNA quantification per nucleus $(\mathrm{A}=$ triploid oyster, $\mathrm{C}=$ diploid oyster). B and D: histograms (FL2-area) showing typical pics: beads used as internal standard (cytometer stability) and nucleus from triploid (B) or diploid (D) oyster: mean level of fluorescence for triploid pic is 505 (Arbitrary units A.U., CV = 3.82) and 333 for diploid (A.U., $\mathrm{CV}=5.02$ ) leading to a ratio of 1.52 .

Figure 3: Microscopic observations of gonadal tubules of triploid Crassostrea gigas: Female $\beta 1$ (A), Female $\beta 2$ (B), Female $\alpha(C)$, male $\beta 1$ (D), male $\beta 2$ (E), male $\alpha(F)$ and hermaphrodite $\beta(\mathrm{G})$, hermaphrodite $\alpha(\mathrm{H})$. GT: gonadal tubules; CT: conjunctive tissue; Oc: oocyte, Spd: spermatid; Spz: Spermatozoa. Scale bars correspond to $50 \mu \mathrm{m}$.

Figure 4: Paralytic shellfish toxin (PST) content in the digestive gland of triploid oysters Crassostrea gigas exposed to a natural bloom of Alexandrium minutum (bay of Daoulas, France) depending on sex and gametogenesis pattern : $\alpha$ (significant gamete production) or $\beta$ (rare gamete production) (Mean $\pm \mathrm{SE}, \mathrm{n}=3-11$ ). No significant differences were found in PST levels depending on sex or gametogenesis pattern (two-way ANOVA, p>0.05). 
Figure 5: Paralytic shellfish toxin (PST) in the digestive gland of triploid oysters Crassostrea gigas exposed to a natural bloom of Alexandrium minutum (bay of Daoulas, France) depending on gametogenesis pattern $\alpha$ (significant gamete production), $\beta 1$ (rare gamete production without any continuum in germ cell lineage) and $\beta 2$ (rare gamete production with a continuum in germ cell lineage) (Mean $\pm \mathrm{SE}, \mathrm{n}=18 ; 7 ; 14$ respectively). No significant differences were found in PST levels between gametogenesis pattern ( $t$-tests, $p>0.05$ ) 


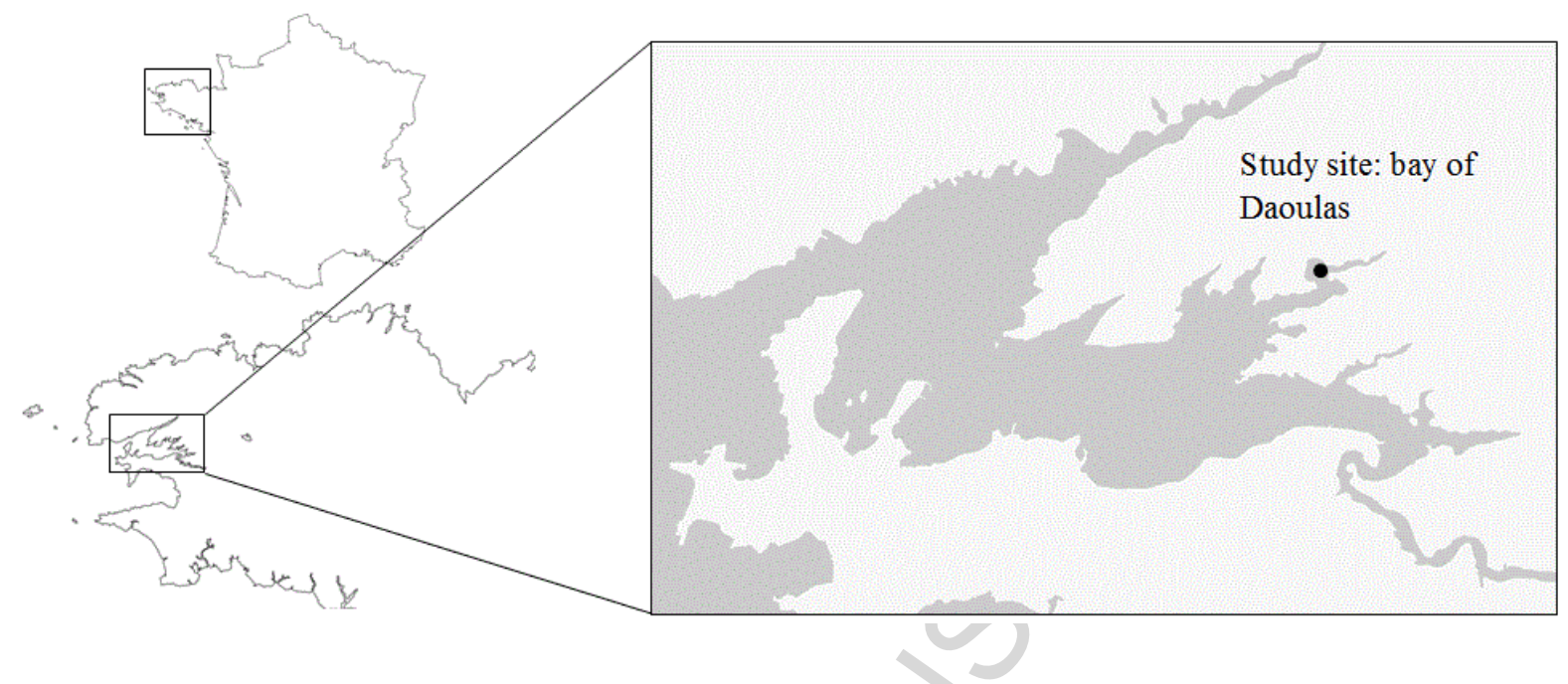

Figure 1 

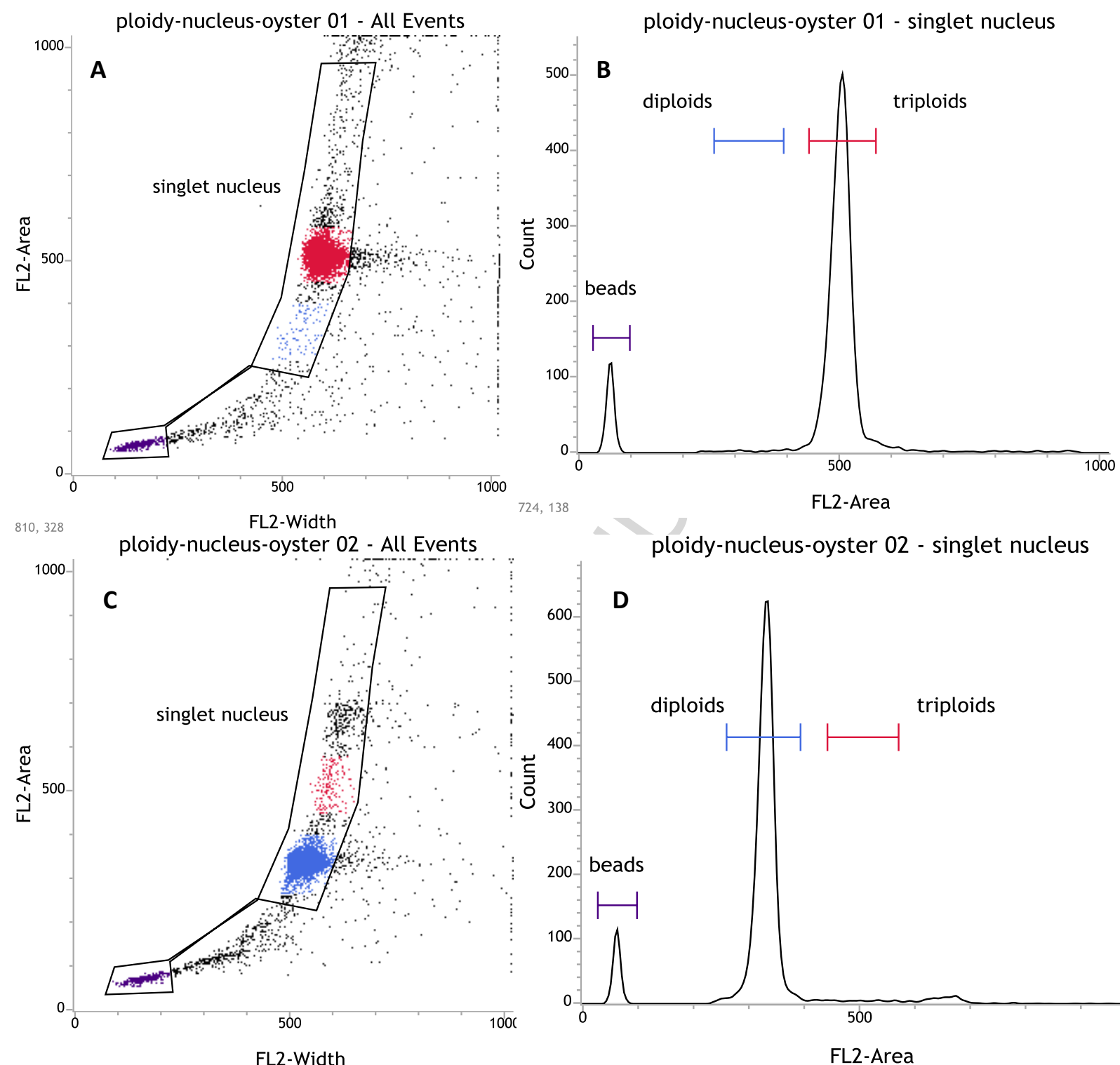

ploidy-nucleus-oyster 02 - singlet nucleus

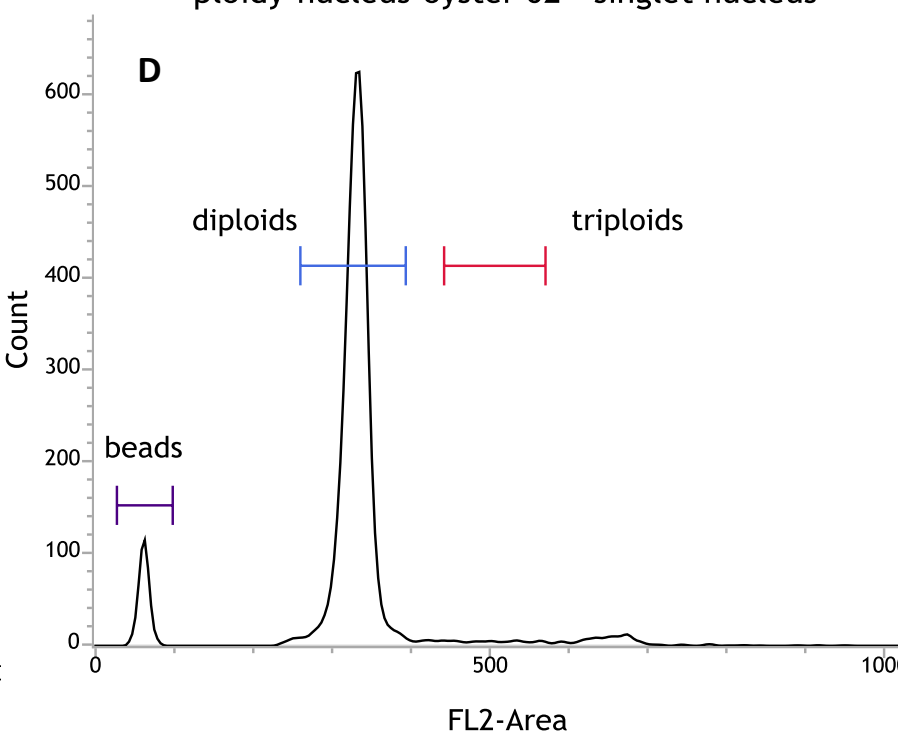

Figure 2 
Figure 3

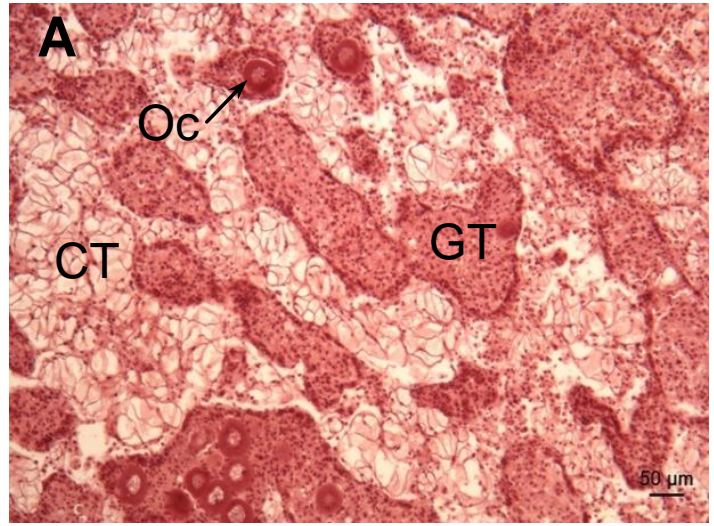

(C)

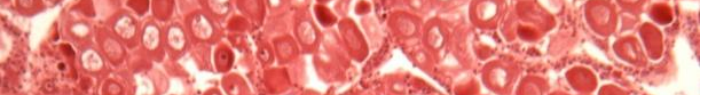
- Fo jo GTo $2400^{\circ}$ \& ${ }^{\circ}+1002$

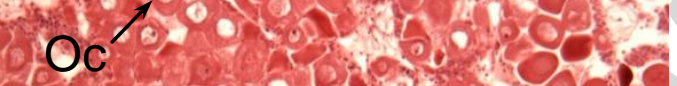
ofor ra -

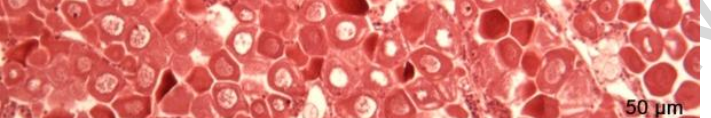
1)
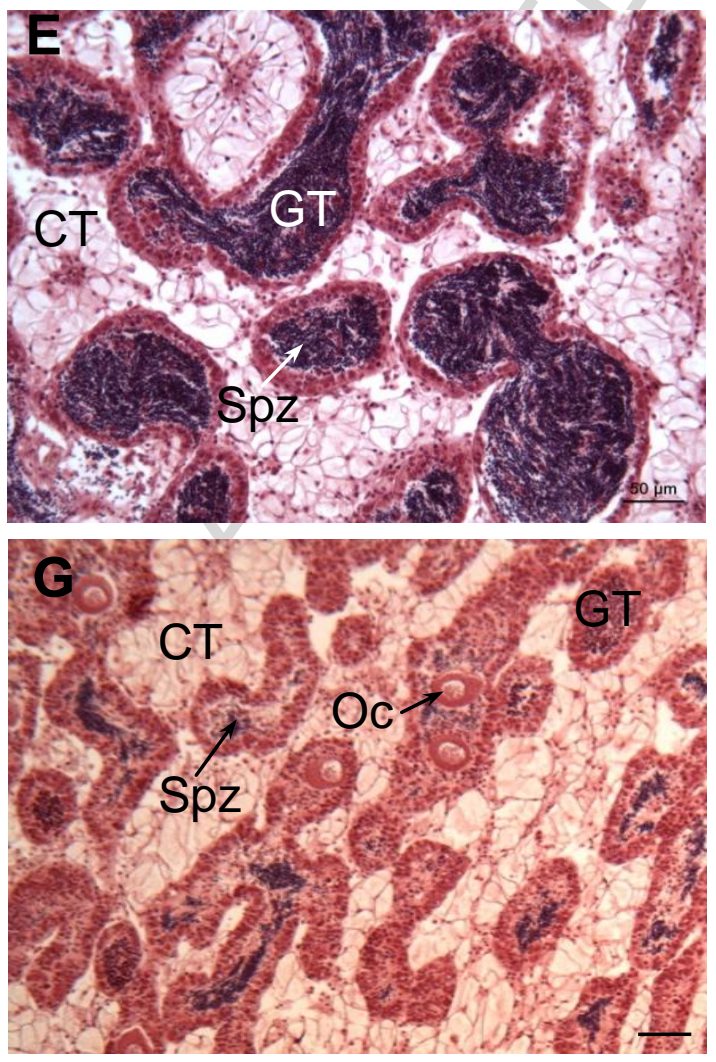

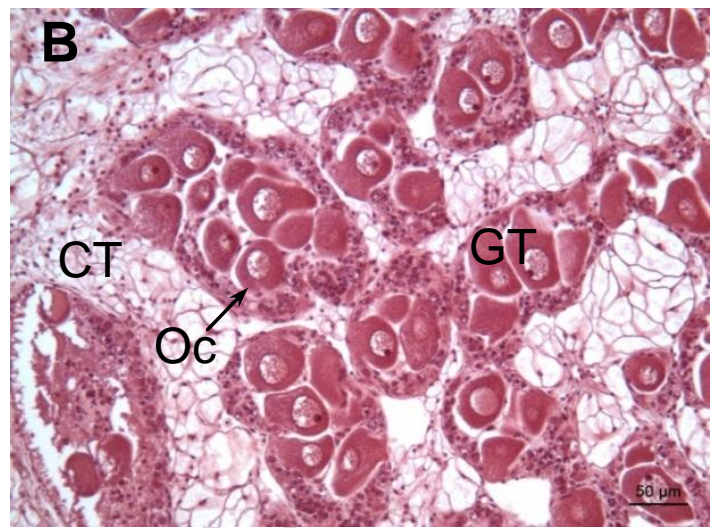

D

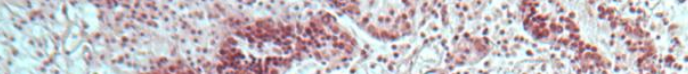

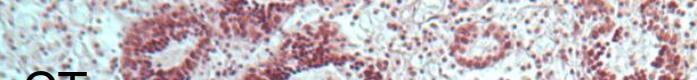
GT

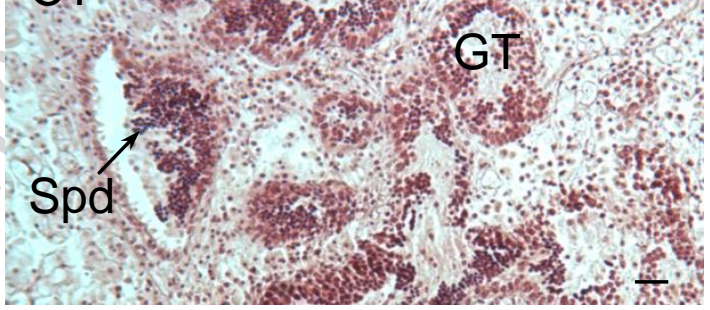
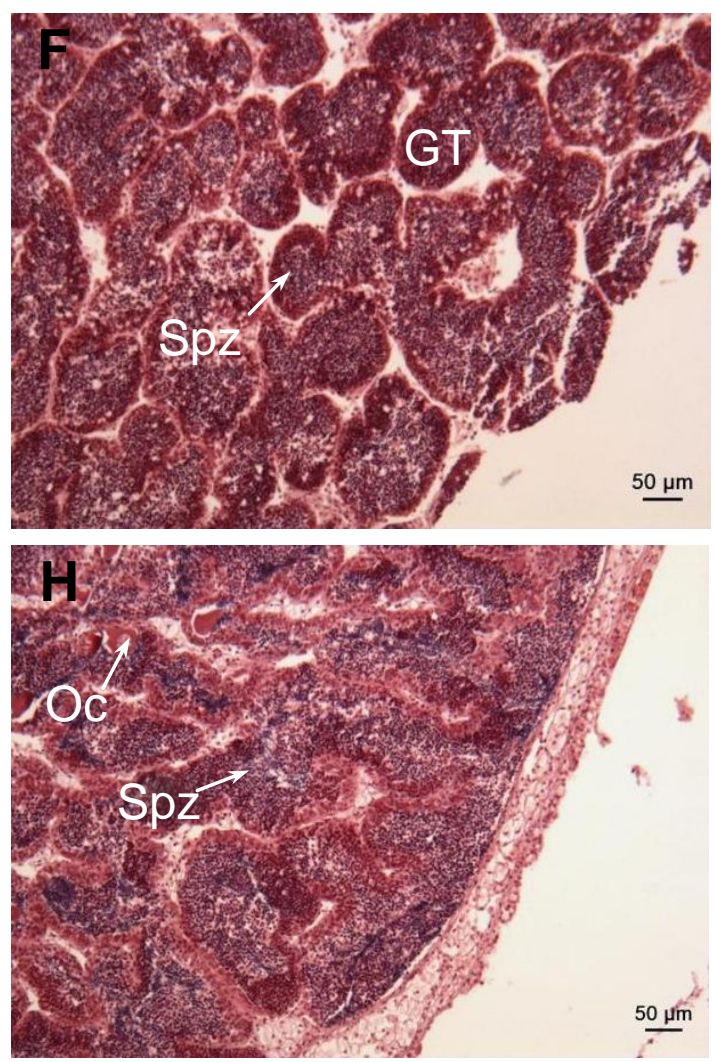


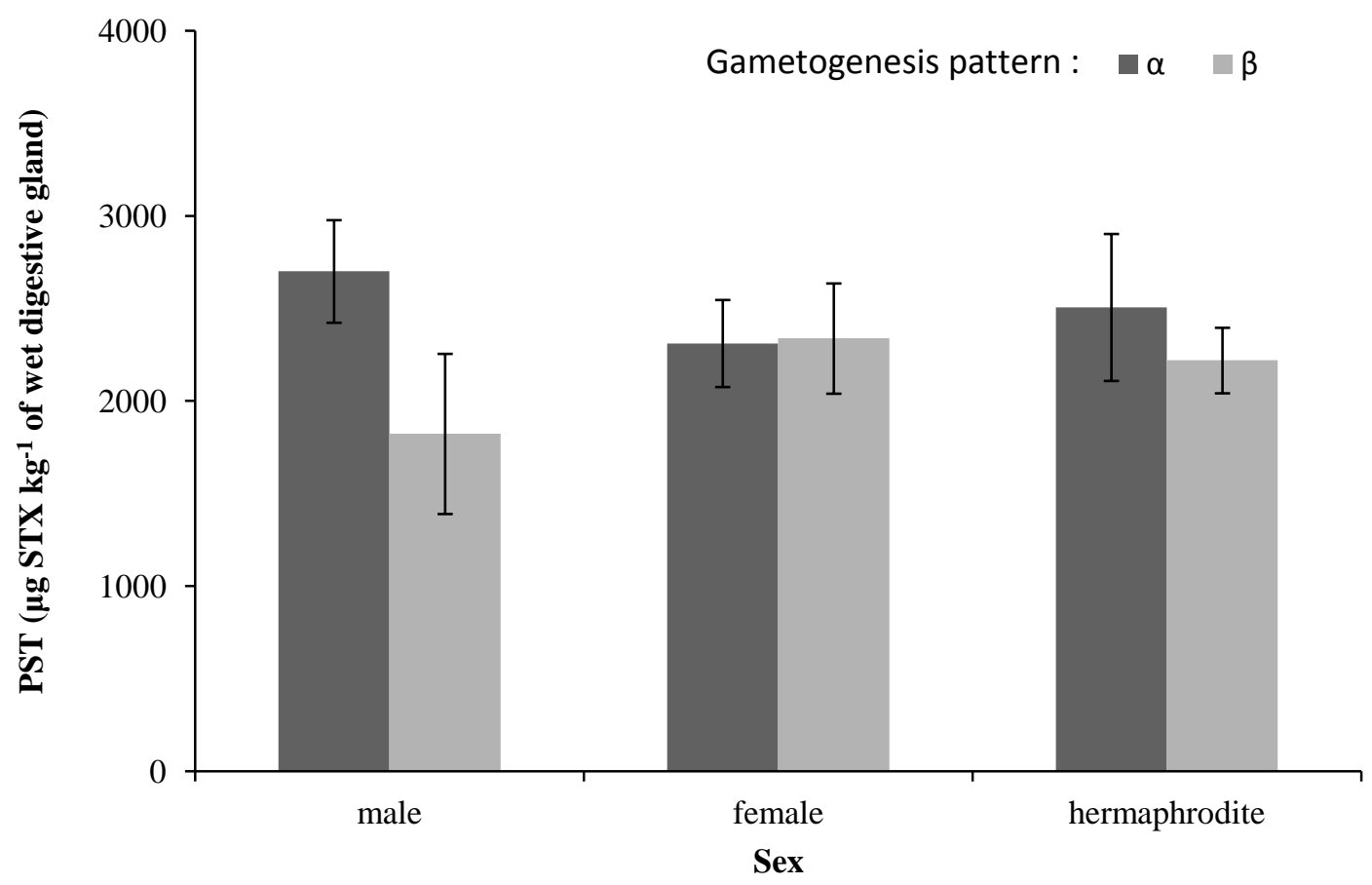

Figure 4 


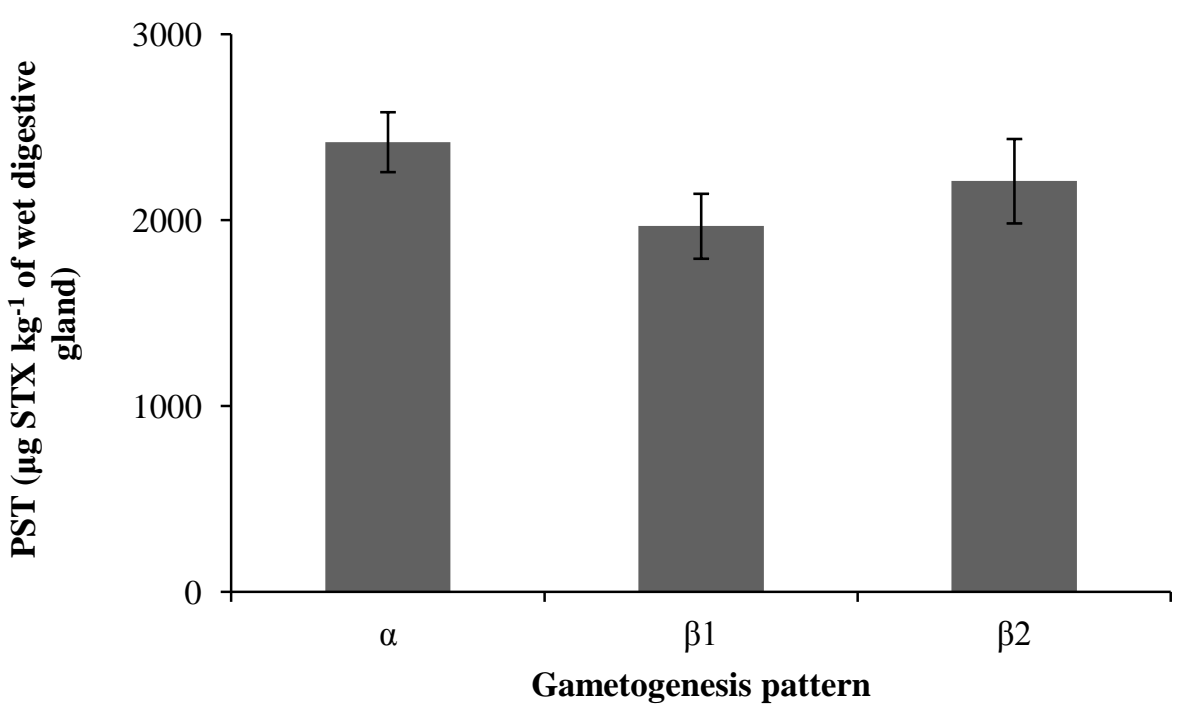

Figure 5 
Table 1: Distribution of $\alpha$ and $\beta$ triploid oysters depending on sex and expressed as percentage of the total, with the actual number in-between parentheses.

\begin{tabular}{ccccc} 
& Male & Female & Hermaphrodite & Total \\
\hline$\alpha$ & $8 \%(3)$ & $28 \%(11)$ & $10 \%(4)$ & $\mathbf{4 6 \% ( 1 8 )}$ \\
$\beta$ & $16 \%(6)$ & $10 \%(4)$ & $28 \%(11)$ & $\mathbf{5 4 \% ( 2 1 )}$ \\
Total & $\mathbf{2 4 \% ( 9 )}$ & $\mathbf{3 8 \% ( 1 5 )}$ & $\mathbf{3 8 \% ( 1 5 )}$ & $\mathbf{1 0 0 \% ( 3 9 )}$
\end{tabular}

